\title{
Too Few Indians and Too Many Chiefs. Is This One Reason for Declining Trade Union Membership in Denmark?
}

\section{Søren Voxted}

Associate Professor in Change Management, University of Southern Denmark, Denmark

\section{Jens Lind}

Associate Professor in Industrial Relations, Aalborg University, Denmark ${ }^{1}$

\begin{abstract}
The decline in trade union membership in many countries since the 1970s and the consequent weakening of the trade unions is due to a number of reasons, including occupational changes, welfare state and social regulation, liberalism and individualization, and in Denmark (and Sweden and Finland) changes in unemployment insurance legislation and the institutional settings of the unemployment insurance system. All these factors are well known and have been analyzed in the literature. This article sums up all these facts and reasons for trade union decline in Denmark, but the main analysis focuses on a supplementary reason for membership decline among LO (the Danish Confederation of Trade Unions)-affiliated unions: many trade union members leave their unions to become members of unions that organize managers. When workers become managers, some prefer to join an organization expert in servicing managerial staff, while others leave their trade unions because they define themselves as managers without being formally appointed as such and without having formal managerial responsibilities. Reasons for this behavior will be discussed in the article.
\end{abstract}

\section{KEY WORDS}

Industrial relations / management / membership of trade unions / organization of work / trade unions / work life changes

\section{Introduction}

rade unions have always been the main social institutions in capitalist societies to represent worker interests in the labor market and, together with labor parties, in the wider society. The decline in membership in many countries since the 1970 s and the consequent weakening of trade unions is a serious threat to acceptable and fair working and living conditions for workers. In Denmark, trade union membership rates peaked in the mid-1990s at around $80 \%$ of the labor force. In 2010, membership rates were below $75 \%$. The loss of members has exclusively been among trade unions in the LO's (Danish Confederation of Trade Unions) main organization, which organizes blue

\footnotetext{
${ }^{1}$ Jens Lind, Associate professor in industrial relations, Aalborg University, Denmark, E-mail: jlind@id.aau.dk
} 
and white collar workers, while the FTF (Confederation of Professionals in Denmark) and the AC's (Danish Confederation of Professional Associations) main organizations, which are for semi-skilled and highly skilled professionals, have gained members. In 1995, the LO unions organized $70 \%$ of all trade union members but in 2010 the LO unions' share of trade union members had declined to $59 \%$.

Some of the main reasons for membership decline are occupational changes, welfare state and social regulation, liberalism and individualization, and in Denmark (and Sweden and Finland) changes in unemployment insurance legislation and the institutional settings of the insurance system. This article will sum up these facts and reasons for trade union decline in Denmark, but the main analysis focuses on a supplementary reason for the membership decline among LO-affiliated unions: many trade union members leave their unions to become members of unions organizing managers. From 2005 to 2010, more than 20,000 LO union members changed membership from an LOaffiliated unemployment fund to the LH (Danish Association of Managers and Executives) unemployment fund. This change may indicate that the LO unions lose many members to "unions" organizing managerial staff and this migration away from the LO will be analyzed and discussed in this article.

Some workers have always been appointed to managerial functions, but it is a bit astonishing that every year 3,000-5,000 workers become managers. This article discusses the reasons why some workers consider themselves as managers - some without being formally appointed at such and without management responsibilities. Some of the main reasons may be that new principles of work organization create job functions that incorporate an element of management and that defining management has become increasingly unclear in recent years.

Finally we analyze what approaches LO-affiliated unions can take in response to membership loss for the above-mentioned reason.

\section{Trade union membership losses in Denmark}

In most countries, membership rates peaked between 1975 and 1985 (France, Germany, Italy, the Netherlands, UK), while unions in other countries were doing well till the mid1990s (Belgium, Norway, Denmark, Finland, Sweden) (Eironline 2004). Throughout the 1980s and the 1990s, unions searched for fresh ways to attract members by introducing new services and finding new strategies, but these efforts failed to curb the loss of members (Figure 1).

The trade union membership loss is most frequently explained by a changing industrial and occupational structure, where the number of workers in manufacturing industries is on the decline, but service sector and knowledge society occupations are on the rise. Changes of this nature mean a concurrent weakening of social democracy and the ideas of a collectivist and solidarity welfare state as well as the revival of liberalist ideas, which not only abandon Keynesianism and revitalize the less interventionist strategies of monetarism but also include an ideological reorientation that puts the individual in focus. In working life, "the end of mass production," with its ideas of restructuring workplace organization in terms of "new production concepts," post-Fordism and flexible specialization, was accompanied by a focus on the individual and the individual's potential and capacities. Human resource manage- 
Figure I:

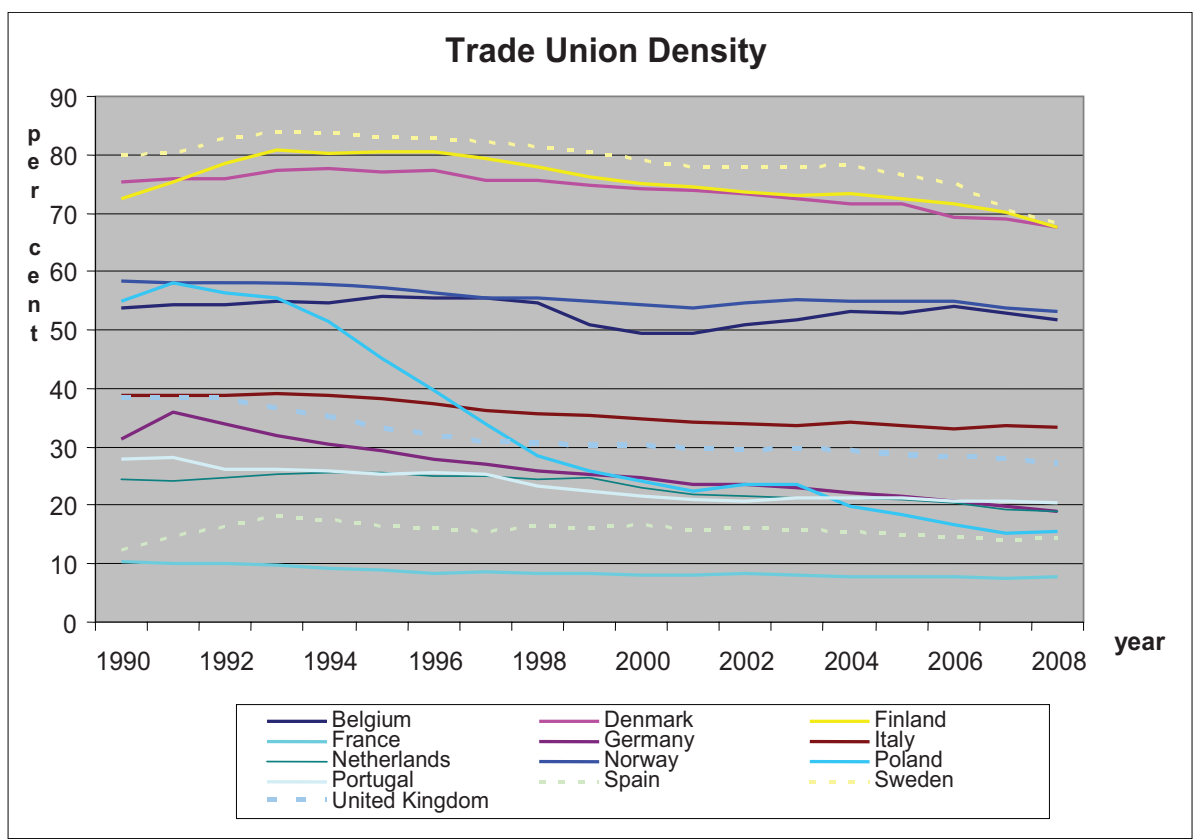

Source: OECD.stat.

ment (HRM) became the modus vivendi for personnel policies instead of industrial relation.

Most theories on trade union member recruitment depart from the notion that becoming a trade union member is the result of a rational choice mainly based on economic reasons. It is, however, disputed whether trade union membership actually provides an economic benefit to the individual worker. If other workers secure favorable conditions, then individual workers stand to benefit without being a union member. Consequently, "To attract members, [unions] must persuade workers to ignore their own narrow financial interest to contribute to a collective project where success or failure depends on the action of others" (Friedman 2008:59). Visser (2002) suggests that other reasons for the loss of members are the fact that the unions do not deliver the expected services or that they cannot maintain a profile that ensures that workers are willing to share the norm being promoted. One main reason workers join trade unions is to be better protected against the competition in the labor market while selling their labor at the best possible price and obtaining the best possible work conditions. As Waddington and Whitston (1997) show, this is still the main reason people join a trade union as opposed to the plethora of insurances, travel, and other consumer-related services used to attract members in the 1980s and the 1990s.

The mode of labor market regulation also affects the propensity of individuals to become a union member. In countries where the conditions for the exchange of labor are mainly regulated by means of collective agreements, trade unions should have a solid 
base for recruiting members, while in countries where the state sets standards for pay and other working conditions, union membership must be based on other reasons such as the ability to influence, e.g., state policies (legislation) and ideological orientations (Lind 1995).

Variation in the trade union membership rates in European countries also depends on the characteristics of the bargaining system. Multi-employer bargaining and an inclusive bargaining system may increase trade union membership (Visser 1991), but it can also often result in a growing problem with free-riding. The low level of multiemployer bargaining, for instance, may be a partial explanation as to why voluntarism in the UK is accompanied by a low union membership rate, while it is much higher in Scandinavia. Systems with a high degree of state regulation also vary concerning trade union membership rates. Exceptionally low membership rates can be found in France and Spain, while rates hover around average in Portugal and Italy. Thus, even though this dimension may potentially explain membership rates, it is nevertheless necessary to go into further detail to explain the variation.

The difference between the UK and Scandinavia is not only due to the fact that collective bargaining and the organizational structure are much more decentralized in the UK than in Northern Europe but also due to the fact that the three countries with the highest membership rates - Denmark, Finland, and Sweden - have a Ghent system, i.e., unemployment insurance based on voluntary membership in unemployment funds often controlled and operated by trade unions (in contrast to compulsory unemployment insurance). Workers tend to become union members to a higher degree in countries with a Ghent system than in other countries that do not have a voluntary system of unemployment insurance organized and administered by unions. Accordingly, there is little doubt that the unemployment insurance system is a major factor in the development of trade union membership rates and is one of the main reasons for the decline in membership rates in recent years. When workers in the Ghent countries join the unemployment insurance funds, they also tend to join a trade union (Lind 2009).

In Denmark, membership losses have mainly taken place among unions affiliated to the LO main organization (Landsorganisationen). Since the mid-1990s, LO-affiliated unions have lost more than 300,000 members while unions affiliated with the other two main organizations, the FTF (Funktioncer-og Tjenestemandsforbundet) and the AC (Akademikernes Centralorganisation), have gained members, as is the case for trade unions outside these three major organizations. This means that the LO share of total membership has declined from around $70 \%$ in the mid-1990s to below $60 \%$ in 2010 , cf. Tables 1 and 2 .

The LO membership losses can be ascribed to the general reasons for membership decline mentioned above. The changing industrial and occupational structure is a basic reason as the LO member unions typically organize blue and white collar workers with little or no education, including unskilled workers, skilled workers in manufacturing and construction, and low-skilled shop and office assistants. The FTF member organizations mainly organize semi-skilled service sector professionals and technical staff, while the AC unions organize staff with an academic degree. In a Danish context, a further reason for declining membership in LO unions and the stable development of FTF and AC unions is the Ghent effect, which has especially hit the LO unions (Lind 2009). 
Table I Members of trade unions in Denmark (000)'.

\begin{tabular}{lccccccccccc}
\hline & 1970 & 1980 & 1990 & 1995 & 1998 & 2000 & 2002 & 2004 & 2006 & 2008 & 2010 \\
\hline Labor force* $^{\prime}$ & 2027 & 2384 & 2669 & 2648 & 2639 & 2659 & 2672 & 2656 & 2667 & 2723 & 2718 \\
\hline LO & 894 & 1250 & 1423 & 1510 & 1484 & 1459 & 1433 & 1386 & 1339 & 1251 & 1201 \\
\hline FTF & 156 & 277 & 325 & 332 & 344 & 350 & 356 & 359 & 363 & 359 & 358 \\
\hline AC & - & 70 & 103 & 132 & 143 & 150 & 161 & 165 & 166 & 174 & $186 * *$ \\
\hline Outside LO,FTF,AC & $11 \mid$ & 197 & 201 & 189 & 195 & 202 & 201 & 217 & 246 & 278 & 305 \\
\hline All trade unions & 1162 & 1794 & 2051 & 2163 & 2166 & 2161 & 2151 & 2127 & 2114 & 2062 & 2050 \\
\hline$\%$ of labor force & 57 & 75 & 77 & 81 & 82 & 81 & 81 & 80 & 79 & 76 & 75 \\
\hline
\end{tabular}

*Self-employed not included, **including engineers, estimated.

Note:The Free Trade Union in Denmark (Danmarks Frie Fagforeninger) not included.

Source: Statistics Denmark.

Table 2 The confederations' share of total membership (\%).

\begin{tabular}{lccccccccccc}
\hline & 1970 & 1980 & 1990 & 1995 & 1998 & 2000 & 2002 & 2004 & 2006 & 2008 & 2010 \\
\hline LO & 77 & 70 & 69 & 70 & 69 & 68 & 66 & 65 & 63 & 61 & 59 \\
\hline FTF & 13 & 15 & 16 & 15 & 16 & 16 & 17 & 17 & 17 & 17 & 17 \\
\hline AC & - & 4 & 5 & 6 & 7 & 7 & 7 & 8 & 8 & 8 & 9 \\
\hline Outside LO,FTF,AC & 10 & 11 & 10 & 9 & 9 & 9 & 9 & 10 & 11 & 13 & 15 \\
\hline
\end{tabular}

Source: Own calculations.

In addition to these reasons for loss of members, there is a supplementary factor which has not yet been considered in the discussion. One special feature of the occupational changes taking place is the growing proportion of workers who become part of management and consequently leave traditional unions for workers who are not part of management.

\section{Trade union members leave to join unions for managers}

Most - if not all - FTF- and AC-affiliated unions have no rules against organizing lower or middle management employees. This is a tradition stemming from the professionally and educationally based organizational pattern. LO, however, has always had a clearer worker orientation arising from a basically adversarial attitude toward management based on a social democratic ideology. Employers share the same idea: managers should not be organized in trade unions that organize ordinary workers and should organize if anywhere - in organizations for managerial staff. Until recently, this order was stipulated in the main agreement $(\mathbb{S} 5)$ between the LO and the employers' main organization, the DA, but in 2007 this paragraph was suspended as it did not correspond to legislation granting the right to freely choose an organization (DA-LO 2007).

This change provided the space for an internal debate to take place in LO-affiliated unions and the main outcome was the opinion that there would be no obstacle for the 
Table $3 \mathrm{LH}$ and LA membership and the movement of members between $L A$ and unemployment funds affiliated with LO trade unions.

\begin{tabular}{lccccc}
\hline & $\begin{array}{c}\text { Danish Association of } \\
\text { Managers and Executives (LH) }\end{array}$ & $\begin{array}{c}\text { Managers' Unemploy- } \\
\text { ment Fund (LA) }\end{array}$ & $\begin{array}{c}\text { From LO } \\
\text { to LA }\end{array}$ & $\begin{array}{c}\text { From LA } \\
\text { to LO }\end{array}$ & $\begin{array}{c}\text { Net from } \\
\text { LO to LA }\end{array}$ \\
\hline 2005 & 76,000 & 84,000 & 2,400 & 900 & 1,500 \\
\hline 2006 & 74,000 & 82,000 & 2,900 & 700 & 2,100 \\
\hline 2007 & 74,000 & 82,000 & 4,200 & 800 & 3,400 \\
\hline 2008 & 76,000 & 84,000 & 3,700 & 700 & 3,000 \\
\hline 2009 & 80,000 & 86,000 & 3,600 & 700 & 2,800 \\
\hline 2010 & 83,000 & 91,000 & 3,500 & 700 & 2,700 \\
\hline Total exchange between LO to LA 2005-2010 & & 20,300 & 4,500 & 15,500 \\
\hline
\end{tabular}

Source: Statistics Denmark, Pensionsstyrelsen, LO (2010c).

unions to organize low and mid-level managerial staff. Because of its significant loss of members, the LO decided to examine in 2010 the extent to which LO unions lost members to unions organizing managers.

The most important specialized organization for managerial staff is the $\mathrm{LH}$, which organizes individuals from both the public and private sectors as well as from among employed staff and the self-employed.

As shown, the LO-affiliated unions have lost on average 50,000 members per year in the past five years or so, cf. Table 1 . The statistics on membership of unemployment funds can be applied to find out how much of this membership decline is due to LO members switching to LH. Although this does not present an exact measure of trade union membership changes, it provides an indication of what the situation is like. ${ }^{2}$ Table 3 shows that the net membership loss of LO unemployment funds to the unemployment fund affiliated with the LH, namely Managers' Unemployment fund (LA), from 2005 to 2010 , is 15,500 or around 2,500 annually. If this migration between the unemployment funds is assumed to resemble the migration pattern between the LOaffiliated unions and the LH, approximately $5 \%$ of the LO membership losses can be ascribed to members switching to the LH. In reality, the migration between the unions and the LH may be smaller than that between the unemployment funds because workers can leave an LO-affiliated unemployment fund and join the LA without leaving the LO-affiliated union. Our calculations are based on the assumption that such cases are relatively rare. ${ }^{3}$

This does not represent by far a decisive proportion of the LO membership losses, but it still contributes to the ongoing drain in membership, which causes concerns about how LO unions can maintain their strength and influence in the labor market.

One main reason for this traffic may simply be that workers increasingly become managers, but perhaps other reasons exist.

The LO carried out a survey in 2010 to map the attitudes of managers about LO union membership ${ }^{4}$ regarding their trade union membership and preferences (LO 2010c). The main conclusions of the survey are as follows: 
- $30 \%$ of the managers who are LO members have personnel responsibilities compared with $61 \%$ among LH members;

- $51 \%$ of the LO managers find the trade union fee to be too expensive compared with $18 \%$ among LH managers;

- LH managers are more satisfied with their union compared with LO managers;

- around half of the members have been in contact with their union within the past three years;

- $53 \%$ of the LO managers and $44 \%$ of the LH managers find that whether or not ordinary workers and managers are in the same union is not of significance;

- other managers recommend their managerial colleagues to become LH members;

- more LH managers (83\%) than LO managers (53\%) prefer their union to be nonpolitical;

- $50 \%$ of the LO managers have considered leaving their union to be unorganized $(19 \%)$ or to become a member of another union (31\%) (LO 2010c).

These unflattering findings indicate that the LO unions are facing persistent problems that have to be dealt with to avoid a future membership loss among the trade union members who consider themselves to be managerial staff. ${ }^{5}$

\section{Why do more Indians believe that they are chiefs?}

An obvious explanation as to why employees move to LH (manager's union) or completely leave any kind of organizing is that they become managers complete with a formal title and also have responsibility for personnel management. Changes in the private and public sectors, like new technology (especially ICT), new work organizations, decentralization of decision making, and the division of labor inside organizations and between independent organizations have increased the need for (formal) managers (Voxted 2011). An increasing number of formal managers nevertheless represent only a limited part of the explanation.

In many ways, it is unclear who the managers in modern organizations are. In today's working life, many employees perform activities and make decisions that resemble the functions of a manager. As a result, many employees call themselves manager without having been given a formal title or having responsibility for personnel management. Broadly speaking, a large proportion of trade union members independently decide that they are managers or coordinators without colleagues considering this as wrong or creating amazement. This self-promotion is evident from the above-mentioned survey, which shows that $67 \%$ of the respondents indicate they are managers, but without a formal title as manager and without responsibility for personnel management. A surprising $40 \%$ of LH members describe themselves as self-appointed managers of this kind, but it is important to keep in mind that LH accepts trusted staff with a high level of responsibility as members (Lederne 2010). Among the LO union members who responded, the amount is more than $70 \%$ (LO 2010c:7).

The proportion of employees who consider themselves as managers seems to have increased in the approximately past 25 years. According to a survey from 1985 covering a similar audience (Fællesudvalget 1985), only $20 \%$ of the respondents called themselves managers without responsibility for personnel management compared with $67 \%$ in the LO's 2010 survey. 
The following analysis focuses on the reason why a significantly increasing number of LO members define themselves as managers, as reflected (see above) by the fact that they leave their trade unions in favor of organizations for managers. Although several explanations unquestionably exist for this trend, the analysis in this article confines itself to just one: current changes as a consequence of developments in working life.

\section{Changes in working life}

Changes in the organization of work have led to a far larger number of supervisory tasks. The functional explanation is that the demands of working life require an increasing number of employees who assume supervisory tasks for the purpose of handling these changes. The challenges facing organizations impose new tasks and require different qualifications, which subsequently lead to changes in formal managerial functions and in what employees are expected to do. Management and organizational literature has a copious amount of examples of how changes, such as the introduction of new technology, team work, quality control systems, etc., have led to the setting of new agendas for the exercise of managerial authority in both the private and the public sectors (e.g., Bach and Sisson (eds.) 2000, Exworthy and Halford (eds.) 1999, Pearce and Conger (eds.) 2003, Pearce and Manz 2005). Likewise, according to both Danish and international quantitative surveys, organizational changes of this nature are widespread and of increasing significance (Arundel et al. 2006, Lundvall 2002, Nielsen 2006).

One result of such changes is that organizations are in an ongoing process that is moving from a system composed of clear roles and positions to one that comprises disintegrating positions and situational roles (e.g., Larsen 2010, Pearce and Conger 2003). The traditional and mechanical organization is characterized by clear and predefined roles. The operator level is responsible for the execution of the work and (in some cases) well-defined/tradition-bound, albeit limited, coordination tasks. The staffs carry out planning and expert functions within a structure that ensures coordination with line management. And the role of the managers is to coordinate the work and constitute a link between line and staff that reaches to the top of the hierarchy. Current trends in organization and management have led to these roles having a broader content over time. In addition, this late-modern development constitutes a transformation that challenges and (partly) dissolves the traditional distribution of roles as a result of current changes. The relatively permanent roles that remain are currently being handled by all three categories of employees (operators, supervisors, and members of staff) based on situational criteria, which in itself require the individuals involved to reflect upon their roles as well as on the expectations of others with regard to the content of specific functions. Before expounding on this further, a brief definition of management is provided.

\section{What is management?}

The underlying basis for this article is that, unlike previously, it is no longer possible, to the same extent, to equate "management" or "leadership" with "managers" as a formal title and position in an organization. In the current labor market situation, there is a need for distinguishing between management/leadership exercised by formal managers 
and management/leadership as an activity. The purpose of this distinction is to illustrate that employees other than those formally appointed to undertake managerial tasks have a real responsibility for tasks previously associated with formal managers.

Classical management theory (e.g., Fayol 1949, Mintzberg 1973) generally equates management with the role of managing. The widespread definition of supervision is that someone (the manager) carries out a task through others. Gary Yukl (2002:8), for instance, defines leadership (management) as, “... the process of influencing others to understand and agree about what needs to be done and how to do it, and the process of facilitating individual and collective efforts to accomplish shared objectives." This definition presupposes that management/leadership and the role of manager involve authority over other employees.

Management, however, may also be viewed as a more broadly defined activity. For this purpose, it will be convenient to make a general distinction between the execution of work and the coordination and control of the work. The performance of the work is the actual production processes. The term production processes involves a far broader range of activities than the production of goods and services. The coordination of the work involves the tasks necessary for the performance of the work, such as coordination, supervision, and control of work processes. As such, all jobs include elements of both performance and coordination. The manager's job alone presupposes coordination, even if the managers are responsible for coordinating the work of the employees.

In accordance with this, the management is linked to the coordination and control of the work. However, it is not possible to equate coordination and control with management (or leadership). By far the majority of employees coordinate their own work to some degree, without this turning them into supervisors. And it makes no difference that the coordination of one's own work can be referred to as self-management. What makes a difference is whether the individual undertakes tasks involving the coordination of the work of others (colleagues) and that this person, without any official title, is authorized by the organization to perform this function. According to the data discussed in this article, an increasing number of employees have managerial tasks without having the formal title of a manager.

\section{Recent developments in the organization of work}

Our analysis expounds on the hypothesis that the changed perspective on management from that of a formal function and role to an activity provides an opening to understanding why an increasing number of employees consider themselves as managers. The reason they do this is to be found in the development of positions in the organization that were formerly rigid into ones that are more flexible. In Denmark, organizations were generally previously composed of three categories of employees.

Manufacturing and service production, for instance, in the trade, transportation, and tourism industry, were largely in the hands of skilled and unskilled labor. This group was subject to the control of managers, but in many organizations the workers were responsible for planning, organizing, and controlling their own work (Mintzberg 1983, Thomson and McHugh 1995, Voxted 2004, Woodward 1965). The employees were (and are) largely organized by a trade union under the LO. 
In addition to being responsible for personnel management, the formal managers were in charge of planning, coordinating, and controlling the work of the employees. All managers were formally part of the management staff and hence representatives of the employers. In general, the supervisors were either not members of a union or they were members of special organizations for managers, such as LH.

The last category of employees, the staff, was responsible for assisting the supervisors with planning, control, record keeping, and administrative tasks or they contributed with expert knowledge. Line workers and staff were completely separate, and all contracts went through formally appointed managers.

Today, there are examples of organizations with four categories of employees, where each group takes on tasks associated with management or supervision in general. Below is a description of an organization that follows this new pattern.

The employees involved in production are still primarily concerned with the execution of the hands-on work. However, they also simultaneously perform functions associated with coordination, control, and the supervision of operations, i.e., they manage their own work as well as that of their colleagues. In many organizations, professional and skilled employees take part in the planning and control of their own work, which remains a natural part of what these groups of employees do (e.g., Mintzberg 1983, Standing 2009). A rather new aspect of what these groups do involves being assigned lateral tasks of coordination, a topic that this article will also examine. Another angle is that these employees are invited to contribute to the implementation of change (e.g., Busck et al. 2010, Ferlie et al. 1996, Kesting and Ulhøj 2010, Voxted 2008). The staff ${ }^{6}$ performs a double role. Conforming to the classical management model, they remain the experts and assistants of the (senior) management. In performing this role, the staffs are responsible for developing the new systems to be used for indirect control as well as for drafting quality standards, preparing measuring tools, and implementing new technologies in collaboration with line managers. In addition, the staffs become part of the line organization (Voxted 2004, 2010). The sources quoted in this paper, some of which are based on observational studies, all show that the staffs are present and actively involved in operations management.

There are still formal managers at all organizational levels, including middle line and first line managers. Several studies argue that this layer is undergoing professionalization. Professional management is the system in late-modern organizations that chiefly comprises fixed, well-defined roles in the form of individuals appointed as managers who are expected to fulfill specific functions. The point of using the term "professional management" in the context of our analysis is specifically to stress that fixed roles and responsibilities are different from those of operations management. The most important task of the system is HRM, formulation of strategy, and organizational development/ change management, including the motivation/facilitation of employees in accordance with the plans, targets, and visions of the senior management (see, e.g., Bach and Sisson (eds.) 2000, Lind and Voxted 2010, Yukl 2002). As a result, when developing public and private sector organizations, it is necessary to aim at professionalizing middle line management by virtue of the fact that the managers of this system have professional managerial skills that set them apart from those of the other employees. This is in contrast to the classical model under which supervisors did not possess professional supervisory qualifications but carried out their supervision based on qualifications that were similar to those of other employees. The tasks associated with professional management used 
to be placed higher in the organization. Or they were entirely absent. For instance, the constant need for change management that exists today was not a feature of working life in the past.

The present way of organizing has emerged as a result of the changes modern organizations are subject to. One of the effects of change is that work in individual units is becoming increasingly specialized and demands progressively more expert knowledge. Nowadays individual (first line) managers do not have a complete overview of their own organization, which is why management/leadership is more about motivating employees to use their knowledge rather than planning, organizing, and controlling daily work. Leadership also includes being able to weigh activities and the consumption of resources for operational tasks and for ongoing reorganization. Thus, in the organization, professional managers become responsible for implementing change and for handling the opposition that frequently emerges among the members of the organization. This requires up-to-date knowledge on change processes and the utilization of management technologies ${ }^{7}$ that differ from the operational tasks of the classical managerial role. In making this point, it is important to emphasize that in a late-industrial market, we still find formal operational managers undertaking (detailed) planning, organization, and control of tasks as well as job-specific supervision. Under the classical model, these managers were generally formally appointed; this function is now far more flexibly structured and in the model presented here largely performed by functions and roles (employees) from the other systems of the organization.

A new element is that the sharp distinction between employees, managers, and staff has largely disappeared. Developments in the labor market are characterized by speedy, far-reaching changes and increasing complexity, which has called for a more flexible organization where the tasks and responsibilities of the employees increasingly depend on the situational context. As a result, we are witnessing a merging of the three organizational layers. One consequence of this merging is that employees from production and staff take over managerial tasks, i.e., tasks that used to be the responsibility of formal managers. This is seen in various ways, as can be illustrated by three examples:

- Staff members exercise the management of employees in practice and, in many cases, that of formal middle line managers too. These staff members may include staff involved in quality control and planning or employees with specialized knowledge in a particular field. Today, it is typical for members of staff to be in direct dialogue with employees without having to go through their nearest formal manager. The staffs of both public and private organizations often consist of academics, but also LO members such as clerical staff may be part of staff functions.

- Coordinators are employees/colleagues who, on an everyday basis, undertake specific managerial tasks that have been transferred to the employees with the establishment of self-managing teams or similar forms of work organization. A large number of tasks involving job-related supervision, planning, organization, and control are undertaken by teams that in practice handle tasks through coordinators. The way that coordination is handled varies from team to team. A common form of coordination is to assign responsibility to one specific individual for a well-defined task or area. As a result, most groups have several coordinators. Other teams have only one, 
which is either a specific person who becomes a de facto first line manager or where all or some employees take turns at various tasks at pre-arranged intervals.

- Project managers are employees in the line organization or members of staff who are given a leadership role in a project. A project may be a development task or a welldefined production task (such as a building project). Being a project manager is a temporary function, especially in the case of minor change implementation projects and development tasks, where having someone without formal managerial authority appointed as project manager is common.

A shared feature of each of these three categories is that the employees have the authority to carry out management in practice, despite the absence of a formal title. As a result, the concept of management is much more broadly applicable and far greater numbers of employees are involved in management in practice. This is also true for many of the people who belong to the LO unions.

\section{Conclusions and perspectives}

There are several reasons why workers leave trade unions. We focus on a reason that has not been discussed before, namely that some union members begin seeing themselves as managers. As a result they change their trade union membership from workers' unions to unions for managers. Some of them leave their trade unions because they do not want to be in the same union as their subordinates.

A major conclusion here is that an increasing number of LO trade union members with some managerial responsibilities look at themselves as managers even when they do not officially have the title of manager. On the one hand, they are managers because they have responsibility for managerial tasks, but on the other hand, they do not carry the title of manager and, most importantly, they do not have responsibility for personnel management. Although we highlight and argue that organizational change and changes in working life are key reasons for this development, we are simultaneously aware that other reasons may exist as to why some workers see themselves as managers without having formal managerial responsibilities. An example of another reason is the individualization that is occurring in every aspect of late modern society, including participation in the labor market (e.g. Beck 1992, 2000). This development has legitimized and in some circles even confers status on people when they call themselves managers, regardless of whether the employees in fact hold a position in the organization that falls outside the classic definition of manager.

The fact that a growing number of trade union members perform management in practice and that some of them consider themselves to be managers is a challenge for trade unions. Employees who exercise management in practice as, e.g., project managers and co-coordinators have special needs. Placed in a new, difficult position between the formal managers and their colleagues, many of them will ask for training, education, and forums where they can discuss experiences and problems. The issue that trade unions must address is whether or not to organize these specialized employees with their new position in the organization and their resulting special needs. Perhaps the real question is whether or not trade unions actually accept that these employees have certain special needs. If the answer is positive and the trade unions choose to include them as 
members with special needs, the next challenge will be to create a product specifically tailored to this group.

If the trade unions decided to define these employees as members who exercise leadership without formally being managers, there is a need not only to recognize that these employees have a special position in the organization but also to identify what their special needs are. Having already faced this issue, some trade unions have started to organize formal managers and to adapt their products to members who are managers but without the title. Two examples are Trade and Labour (FOA) and the Danish Association of Professional Technicians (Teknisk Landsforbund). The experiences of these two trade unions, other trade unions, and professional associations for academics and semi-academics indicate that in order to keep employees who have managerial tasks, including first line managers, trade unions must cater to their needs with customized products designed to meet the requirements of those members. As the number of employees who exercise managerial tasks is large and continues to expand, this issue clearly must be addressed in both the literature and by trade unions.

\section{References}

Arundel, A. et al. (2006) The organization of work and innovative performance: A comparison of the EU-15, DRUID working paper, no. 06-14.

Bach, S. and K. Sisson (eds.) (2000) Personnel Management, A Comprehensive Guide to Theory and Practice, Oxford: Blackwell Business.

Beck, U. (1992) Risk Society: Toward a New Modernity, Thousand Oaks: Sage Publications.

Beck, U. (2000) The Brave New World of Work, Cambridge: Cambridge University Press.

Busck, O., Kudsen, H. and Lind, J. (2010) 'The transformation of employee participation: Consequences for the work environment', Economic and Industrial Democracy 31(3), pp. 285-305.

DA-LO (2007) Protokollat vedrørende Hovedaftalens \$5, DA-LO, Copenhagen.

Eironline (2004) Trade union membership 1993-2003, http://www.eiro.eurofound.ie

Exworthy, M. \& S. Halford (eds.) (1999) Professionals and the New Managerialism in the Public Sector, Buckingham: Open University Press.

Fayol, H. (1949) General and Industrial Management, London: Sir Isaac Pitman \& Sons, Ltd.

Ferlie, E. et al. (1996) The New Public Management in Action, Oxford: Oxford University Press.

Friedman, G. (2008) Reigniting the Labor Movement, London: Routledge.

Fællesudvalget vedrørende Arbejdsmarkedslederuddannelse (1985) Rekruttering og introduktion af nyudncevnte arbejdsledere, Fællesudvalget vedrørende Arbejdslederuddannelse, Copenhagen.

Kesting, P. and J. Ulhøi (2010) 'Employee-driven innovation: Extending the license to foster innovation', Management Decision, 48(1), pp. 65-84.

Larsen, H. (2010) License to work - Arbejdslivets tryllestav eller håndjern?, Holte: Valmuen.

Lederne (2010) Kan du blive medlem?, www.lederne.dk

Lind, J. (1995) 'The modernisation of trade unions in Denmark', Transfer, 1(1), pp. 44-63.

Lind, J. (2009) 'The end of the Ghent system as trade union recruitment machinery?', Industrial Relations Journal, 40(6), pp. 510-523.

Lind, J. and S. Voxted (2010) New principles of management in modern organizations, paper, IIRA European Congress, Copenhagen, July 2010.

LO (2010a) 'Udviklingen i den faglige organisering: årsager og konsekvenser for den danske model', LO-dokumentation No. 1/2010. 
LO (2010b) Medlemsudvikling I Ledernes A-kasse, LO, Copenhagen.

LO (2010c) Projekt lederinitiativer - Analyse 1, LO, Copenhagen.

Lundvall, B. Å. (2002) Innovation, Growth and Social Cohesion, Cheltenham: Edward Elgar Publishing.

Mintzberg, H. (1980) [1973] The Nature of Managerial Work, Englewood Cliffs, NJ: Prentice-Hall.

Mintzberg, H. (1983) Structure in Fives, Englewood Cliffs, NJ: Prentice-Hall.

Nielsen, P. (2006) The Human Side of Innovation Systems? Innovation, New Organization Forms and Competence Building in a Learning Perspective, Aalborg: Aalborg University Press.

Pearce, C. and J. Conger (eds.) (2003) Shared Leadership: Reframing the Hows and Whys of Leadership, Thousand Oaks: Sage Publications.

Pearce, C. and C. Manz (2005) 'The new silver bullets of leadership: The importance of self- and shared leadership in knowledge work', Organizational Dynamics, 34(2), pp. 130-140.

Standing, G. (2009) Work after Globalisation, Cheltenham: Edward Elgar Publishing.

Thomson, P. and D. McHugh (1995) Work Organizations: A Critical Introduction, Hound Mills: Macmillan Business.

Yukl, G. (2002) Leadership in Organizations, Upper Saddle River, NJ: Prentice-Hall.

Visser, J. (1991) 'Trends in Trade Union Membership', OECD Employment Outlook, Paris: OECD, pp. 97-134.

Visser, J. (2002) 'Why fewer workers join unions in Europe: A social custom explanation of membership trends', British Journal of Industrial Relations, 40(3), pp. 403-430.

Voxted, S. (2004) Arbejdslederrollen under forandring, LEO, Aalborg: Aalborg University and Copenhagen: KLEO, UC København.

Voxted, S. (2008) 'Learning Organizations in Practice', in Christensen, A. (ed.) The Learning Perspective, Aalborg: Aalborg University Press.

Voxted, S. (2010) Establishment of self-governing teams: Equality in working life or a new way of polarization of the workforce, paper, IREC 2010, Oslo, 8-10 September.

Voxted, S. (2011) The new hierarchy, paper, Annual International Conference on Human Resource Management \& Professional Development for the Digital Age (HRM\&PD 2011), Singapore, 7-8 November.

Waddington, J. and Whitston, C. (1997) 'Why Do People Join Unions in a Period of Membership Decline?', British Journal of Industrial Relations, 35(4), pp. 515-546.

Woodward, J. (1965) Industrial Organizations: Theory and Practice, London: Oxford University Press.

\section{Endnotes}

${ }^{1}$ In the following we apply data from Statistics Denmark that differ slightly from the OECD and EU statistics. Our figures include retired people who are still members of trade unions, which means that especially the LO membership figures are overestimated, cf. LO (2010a).

2 Table 3 shows that not all members of the LH-affiliated unemployment fund, LA, are members of LH. This is the same tendency in most unemployment funds and related trade unions. Consequently, we cannot directly deduce that tendencies in unemployment fund memberships are the same as tendencies in trade union memberships; this is nonetheless the best indication on trade union membership available to us.

${ }^{3}$ Workers leave LO-affiliated unemployment funds mainly for financial reasons and because they feel they have no reason to stay in an LO union. These individuals will typically join 
an unemployment fund with no trade union affiliation or one with an affiliation to a union outside one of the main organizations.

${ }^{4}$ Survey participants comprise "managers with an LO background," which is defined based on educational background and trade union membership: "Respondents who have managerial responsibilities and who have primary school, secondary school or a short further education". Managers with a higher education were included if they were a member of an LO union (LO 2010c: Metodenotat p. 1). The sample comprises 1,068 individuals.

${ }^{5}$ The LO unions that mainly lose members to LH are the union for non- and semi-skilled manual workers, $3 \mathrm{~F}$, the union for clerical and shop assistants $(\mathrm{HK})$, and the metal worker union (Metal). This paper, however, does not provide specific details about the process or these unions (LO 2010a).

${ }^{6}$ Staff comprises, e.g., techno structure staff (see Mintzberg 1983), support staff (Mintzberg 1983), office staff and R\&D staff.

${ }^{7}$ The term management technologies refer to systems or tools such as self-managing teams, value-based leadership, LEAN, etc. 